\title{
ISLAMIC EDUCATION DURING LANGKAT SULTANATE ERA IN 1912-1946: \\ A Historical Study of Jam'iyah Mahmudiyah li Thalibil Khairiyah Langkat
}

\author{
Zaini Dahlan \\ STAI Syekh H. Abdul Halim Hasan al-Ishlahiyah Binjai \\ Jl. Ir. H. Juanda No. 5 Binjai, Sumatera Utara, 20732 \\ e-mail: zainidahlanannuri@gmail.com
}

\begin{abstract}
Abstrak: Penelitian ini bertujuan mengungkap pendidikan Islam pada masa Kesultanan Langkat 1912-1946, khususnya tentang Jam 'iyah Mahmudiyah Li Thalibil Khairiyah Tanjung Pura Langkat. Penelitian ini merupakan penelitian sejarah dengan pendekatan sejarah sosial. Hasil penelitian menunjukkan bahwa Jam'iyah Mahmudiyah Li Thalibil Khairiyah menggambarkan lembaga pendidikan modern formal pertama di Sumatera Timur. Dari aspek kelembagaan, Jam'iyah Mahmudiyah memiliki visi misi, struktur organisasi, prasarana dan sarana yang modern, serta pendanaan yang jelas. Pada tahun 1912 Jam'iyah Mahmudiyah mengadakan pembaruan di lembaga tersebut yang dimulai dengan pemberlakuan ujian dan berhak mendapatkan ijazah. Pendidiknya terdiri dari ulama yang memiliki latar belakang pendidikan dari Ummul Qurâ' dan al-Azhar. Menurut penulis hal ini semakin kuat dengan kendali pengelolaan pendidikan yang langsung dikendalikan oleh organisasi yang dibawahi oleh Sultan Langkat.
\end{abstract}

\begin{abstract}
Islamic Education in Langkat Sultanate During 1912-1946: A Historical Study of Jam'iyah Mahmudiyah li Thalibil Khairiyah Langkat. This study aims to reveal the Islamic education during the Langkat Sultanate 1912-1946, especially about Jam'iyah Mahmudiyah Li Thalibil Khairiyah Tanjung Pura Langkat. This research is a historical research with social history approach. The results show that Jam'iyah Mahmudiyah Li Thalibil Khairiyah represents the systematic, planned, modern and first formal education institution in East Sumatra. As for the institutional aspect, the Jam'iyah has a vision of mission, organizational structure, infrastructure and modern facilities, as well as fixed budgeting. In 1912 the Jam'iyah reformed evaluation method, as well as standardized the qualification of the teachers of Umm al-Qurâ' and Al-Azhar. According to the author, the system is getting stronger with the control of education management directly controlled by the organization that was under Sultan Langkat.
\end{abstract}

Keywords: Indonesia, Malay, Langkat sultanate, Islamic education 


\section{Introduction}

Talking about Islamic education in Indonesia, it is absolutely connected to the arrival of Islam in Indonesia. In this context, Yunus argues that Islamic education is as old as the arrival of Islam in Indonesia. ${ }^{1}$ About the arrival of Islam in Indonesia, there are some discussions and long debates among experts regarding three principle issues: place of the arrival, the missionaries and the time of arrival. ${ }^{2}$

Islamic education in Indonesian archipelago started after contacts between traders who also functioned as muballigh and society members in the coastal area. Naturally, the initial education activities were informal ones. ${ }^{3}$ After Islamic society was formed, then the concern is building the house of worship such as mosque, surau, and langgar, ${ }^{4}$ because Muslims are required to worship five times a day and highly recommended to do so in congregation. In addition, mosque, surau, and langgar are not only utilized as places of worship, but also as places of education. This practice was in line with the example shown by Prophet Muhammad SAW., he used Madinah Mosque as place of education. ${ }^{5}$ Mosque is an educational institution which was firstly built beside ulama or muballigh's house. ${ }^{6}$

In time, other Islamic education institutions also emerged such as meunasah, rangkang, dayah, surau and pesantren. Even though the names are different according to regions, basically they are same namely places of seeking religious education. ${ }^{7}$ The different names are influenced by the origin of the places. On subsequent development, in early 1892, Madrasah Maslurah was established. This madrasah in turn inspired the emergence of an Islamic organization, Jam'iyah Mahmudiyah Li Thalibil Khairiyah, officially inaugrated in $31^{\text {st }}$ December 1912 or $22^{\text {nd }}$ Muharram 1331 H. ${ }^{8}$ This means that Jam'iyah Mahmudiyah was

${ }^{1}$ Mahmud Yunus, Sejarah Pendidikan Islam di Indonesia (Jakarta: Mutiara Sumber Widya, 1995), p. 6.

${ }^{2}$ Azyumardi Azra, Jaringan Ulama Timur Tengah dan Kepulauan Nusantara Abad XVII dan XVIII: Akar Pembaruan Islam Indonesia, Revision Edition, $2^{\text {nd }}$ ed. (Jakarta: Kencana Prenada Media, 2005), p. 2.

${ }^{3}$ Referring to Haidar Putra Daulay, Historisitas dan Eksistensi Pesantren, Sekolah dan Madrasah (Yogyakarta: Tiara Wacana, 2001), p. 1.

${ }^{4}$ Haidar Putra Daulay, Sejarah Pertumbuhan dan Pembaruan Pendidikan Islam di Indonesia, ed. 3 (Jakarta: Kencana Prenada Media, 2012), p. 20-22.

${ }^{5}$ See Hasan Asari, Menyingkap Zaman Keemasan Islam: Kajian atas Lembaga-lembaga Pendidikan, $3^{\text {rd }}$ ed. (Bandung: Citapustaka Media, 2013), p. 44-45.

${ }^{6}$ During the classical period of Islam, house was also used as place of Islamic education. For instance, the house of al-Arqam ibn 'Abdi Manâf (w. 55/675) in Makkah, and the house of Abû Ayyûb al-Anshârîy (w. 52/672) in Madinah. Refer to H2asan 'Abd al-'Âl, al-Tarbiyah fi al-Islâmiyah al-Qarn al-Râbi' al-Hijriy (Cairo: Dâr al-Fikr al-'Arabiy, 1978), p. 26. See also in Sa'îd Ismâ'il 'Alî, Nasya'au al-Tarbiyah al-Islâmiyah (al-Qahirah: 'Âlam al-Kutub, 1978), p. 182.

${ }^{7}$ For a general introduction to these institutions see Azyumardi Azra, Islam in the Indonesian World: An Account of Institutional Formation (Bandung: Mizan, 2006).

${ }^{8}$ Fachruddin Azmi, et al., Sejarah Organisasi Pendidikan dan Sosial Jam'iyah Mahmudiyah Li Thalibil Khairiyah Tanjung Pura Langkat (Bandung: Citapustaka Media, 2012), p. 3, 45. A Little 
only slightly younger than Muhammadiyah (established in 1912) but older than other Islamic organizations like Nahdhatul Ulama (1926), Al-Jam'iyatul Washliyah (1930) and Al-Ittihadiyah (1930). Jam'iyah Mahmudiyah pioneered the birth of Madrasah Aziziyah in 1914 and Madrasah Mahmudiyah in 1921, both in Langkat. ${ }^{9}$

This article was based on a social history ${ }^{10}$ of Islamic education during Langkat Sultanate (1870-1946) which focused on Jam'iyah Mahmudiyah Li Thalibil Khairiyah Tanjung Pura. Despite its significant contribution, this institution has so far received very limited attention from researchers. The study will cover institutional developments, the contents of education, teachers and students, and the management.

\section{The Establishment of Jam'iyah Mahmudiyah}

Towards his resignation in 1892, Sultan Musa obtained a deep understanding of Islam, decreasing his activity in politics and more concerned on the development of Islam starting from getting closer to Allah SWT by doing "Suluk" (spiritual path to Allah SWT) following Tariqat Naqsyabandiyah. ${ }^{11}$ In 1889, he went to Mecca with his queen T. Puan Maslurah, and learned from Syaikh Sulaiman Zuhdi ${ }^{12}$ in Jabal Qubis Hijaz. After a year in Mecca, he went back to Langkat, with an ever increasing zeal to spread Islam. In 1892, he established a special madrasah for women, named after his queen "Maslurah". The madrasah was located near the palace in Kampung Dalam, at the riverside of Batang Durian, currently behind Azizi Mosque. In 1893, Sultan Musa descended from the throne giving way to his son, Sultan Abdul Azis. The first principal of madrasah Maslurah was Syaikh Mohammad Ziadah (1858-1941). ${ }^{13}$

A very important development of Islamic education in Langkat took place on $22^{\text {nd }}$ of Muharram 1331/31 $1^{\text {st }}$ of December 1912: a social organization and Islamic education

annotation is that the presence of Madrasah Maslurah apparently gave stimulus for Muslims to build other Islamic institutions. For instance, the establishment of Jami'ah Almuslim Aceh in 1929 by Teungku Abdurrahman Meunasah Meucap (d. 1949). See Saifullah, "Pembaruan Pendidikan Islam di Aceh: Studi Historis tentang Jami'ah Almuslim 1929-2010" (Dissertation: Pascasarjana IAIN Sumatera Utara, 2012).

${ }^{9} \mathrm{Ibid}$. For a general assesments of Islamic organizations in North Sumatera, see Al Rasyidin, "Islamic Organizations In North Sumatra; The Politics of Initial Establishment and Later Development," dalam Journal of Indonesian Islam, Volume 10, Number 1, June 2016.

${ }^{10}$ Hasan Asari, Menguak Sejarah Mencari 'Ibrah; Risalah Sejarah Sosial-Intelektual Muslim Klasik (Bandung: Citapustaka Media, 2006), p. 27.

${ }^{11}$ Sulaiman Zuhdi, Langkat dalam Kilatan Selintas Jejak Sejarah dan Peradaban (Stabat: the Office of Library, Documentation and Archive, Kabupaten Langkat, 2014), p. 67-68.

${ }^{12}$ A. Fuad Said, Syaikh A. Wahab; Tuan Guru Babussalam, ed. 6 (Medan: Pustaka Babussalam, 1991), p. 20.

${ }^{13}$ See in Fachruddin Azmi, et al., Sejarah Ulama Langkat dan Tokoh PendidikJam'iyah Mahmudiyah Li Thalibil Khairiyah Tanjung Pura Langkat (Bandung: Citapustaka Media, 2012), p. 54. For more detail can be seen in L. Hidayat Siregar, "Tariqat Naqsyabandiyah Syaikh Abdul Wahab Rokan," in MIQOT: Jurnal Ilmu-ilmu Keislaman, Vol. XXXV. No. 1, 2011, p. 61-63. 
called “Jam'iyah Mahmudiyah Li Thalibil Khairiyah” was inaugurated by Sultan Abdul Aziz in Tanjung Pura, Langkat. Sultan Abdul Aziz proposed an idea to build an organization and gather all the people's power to mobilize Islamic education for the children who need it with motivation from ulama and community members in Langkat. At the end of 1912, there was a special meeting among Sultan, ulama, and government functionaries which was held in Mosque Azizi in Tanjung Pura. In that meeting, the interest of teaching children and the establishment of a social and educational organization were considered. Sultan authenticated and issued a letter of official recognition with Note (Besluit) No. 102 in 1912 dated $22^{\text {nd }}$ of Muharram 1331/31 ${ }^{\text {st }}$ of December $1912 .{ }^{14}$

\section{Institutional Development of Jam'iyah Mahmudiyah}

This part discusses subsequently about: (1) the objective; (2) the organizational structure; (3) the infrastructures; and (4) the budget.

\section{The Objective}

Literally, 'Jam’iyah Mahmudiyah li Thalibil Khairiyah' means 'Praiseworthy Association to Promote Kindness'. ${ }^{15}$ In the time of establishment of the organization in 1912, there was no clear written vision and mission, perhaps following the general practice of the time. ${ }^{16}$ However it was clear that the purpose of Jam'iyah Mahmudiyah Li Thalibil Khairiyah was to provide affordable education for general people, so that they can have easy access for education. The long term objective of the organization was to increase the dignity of society members in Langkat. ${ }^{17}$

The establishment of Jam'iyah Mahmudiyah Li Thalibil Khairiyah was a part of people's awareness and reformation movement in Islam which was encouraged by various thoughts and opinions from ulama of Al-Azhar namely Jamaluddin Al-Afgani (1839-1897), M. Rasyid Ridha (1849-1905), and Muhammad Abduh (1865-1935). ${ }^{18}$ Moreover, the objective

\footnotetext{
${ }^{14}$ A. Kadir Ahmadi, et al., Sejarah Jamaiyah Mahmudiyah Li Thalabil Khairiyah Tanjung Pura Langkat Sumut (Langkat: The General Manager of Jam'iyah Mahmudiyah Li Thalabil Khairiyah Tanjung Pura, 1994), p. 3.

${ }^{15}$ Fachruddin Azmi, et al., Pengabdian Alumni Sepanjang Masa; Alumni Jam'iyah Mahmudiyah li Thalibil Khairiyah, ed. 1 (Bandung: Citapustaka Media, 2012), p. 28.

${ }^{16} \mathrm{Fakhruddin}$ Ry (84 years old), a Historian from Langkat, interviewed in Stabat, on $1^{\text {st }}$ December 2016.

${ }^{17}$ Ibid.

${ }^{18}$ Fachruddin Azmi, Jam'iyah Mahmudiyah Li Thalibil Khairiyah dan Semangat Kebangsaan (Tanjung Pura: Speech of the Chairman of PB JML at a JML gathering in Syaikh Mohd. Ziadah's main hall, August 20, 2016), p. 4-5. A general introduction to these highly influential thinkers can be found in Albert Hourani, Arabic Thought in The Liberal Age 1798-1939 (London: Oxford University, 1962) and Hasan Asari, Modernisasi Islam: Tokoh, Gagasan dan Gerakan (Bandung: Citapustaka Media, 2002).
} 
of the establishment of this organization was initiated from consciousness and spirit to bring people from stupidity to enlightenment and to confront the influences of colonial thought and culture. It stood on the idea of the ulama to support educational system and teaching, and enhancing the quality of Muslims' life which was Sultan Langkat's priority at that time. ${ }^{19}$

\section{The Organizational Structure}

The organizational structure of the organization underwent changes, as follows: a) Colonial Dutch period (1912-1939); b) Period of Japanese occupation (1939-1944).

\section{Colonial Dutch Period (1912-1939)}

For the very first time in 1912, the organizational structure was the following: The General Manager (Janabul Ali) : Sultan Abdul Aziz Abdul Jalil Rahmatsyah

The Daily Manager (Mudir)

Secretary

Treasure

Assistants
: Raja Muda T. Mahmud bin Abdul Aziz

: Tengku Pangeran Indra Diraja

: Haji Abdullah Omar

: Datuk (headman or the oldest man in a Family clan) Amar Setia Diraja

Tengku Fachruddin (Religious teacher) Haji Zainuddin (Qadhi or judge of the Shari'a Court) Haji Muhammad Thaib (Religious teacher) Haji Muhammad Ziadah (Religious teacher) All of Princes, Vocationals, and Datuk-datuk (the elderlies) of Langkat Sultanate. ${ }^{20}$

That was the structure of organization of Jam'iyah Mahmudiyah. ${ }^{21}$ Meanwhile, the name of educational institution was same as the organization's name that was Madrasah Jam'iyah Mahmudiyah Li Thalibil Khairiyah Tanjung Pura Langkat. When it was first emerged, the levels of education which is under the organization were Tajhizi (kindergarten) Ibtidaiyah (elementary school) and Tsanawiyah (junior high school). So in 1912, H. Muhammad Ziadah was given a mandatory as the head of educational institution with the help of several young

${ }^{19}$ Azmi, Jam'iyah Mahmudiyah, p. 5.

${ }^{20} \mathrm{Ahmadi}$, et al., Sejarah Jamaiyah, p. 4.

${ }^{21}$ The structure that will be discussed in outline here is the structure of organization of Jam'iyah Mahmudiyah, not the structure of educational institution. However, vertically, the head of educational institution is under the organizational structure and is the administrator in Jam'iyah Mahmudiyah. 
teachers. Since that era, the system of education was arranged and regulated under a relatively organized-system according to educational procedures in Mecca. The trust given to him had been used and conducted well in which the education organized orderly, using classroom, using time table of subject simply like a good school at that era. ${ }^{22}$

\section{Period of Japanese Occupation (1939-1944)}

In 1939, the World War II occurred in Asia, where Japan attacked Pearl Harbour and other areas. In the course of the war, Japan occupied Indoensia, replacing the Dutch. The take-over and the instabilty that follows affects the Jam'iyah. The Sultan's position is no longer same. While the Dutch granted the Sultan some amount of autonomy, the Japanese stripped him out of his autonomy and put him under strict supervision so that he cannot exercise his power as before. Besides that, the Japanese government expected helps in terms of energy from people in the form of Tonarigumi, ${ }^{23}$ Romusha, ${ }^{24}$ and others. The youths were forced to participate in Greater East Asia War. ${ }^{25}$ In the Japanese occupation era, the new administrator of Jam'iyah was formed, which consisted of:

The Chief : Tengku Amir Hamzah

Secretary : : Orang Kaya (O.K.) Ibrahim

Assistants : : Tuan Syaikh H. Abdullah Afifuddin (Ulama)

Tuan Syaikh H. Abd. Rahim Abdullah (Ulama)

Additional assistants those are Datuk from Langkat Sultanate.

Sultan himself was still as the General Leadership

$(\text { Janabul Ali })^{26}$

Before Japan occupied Indonesia, Sultan $\mathrm{Mahmud}^{27}$ took action earlier and felt an emergency situation would be occurred. For that reason, all of waqf (charitable trusts) property owned by Jam'iyah, the letter was changed, from Grant Sultan became Grant which is issued by Resident of East Sumatera No. 79 on $10^{\text {th }}$ June 1940 and Sultan's letter No. 75 on $20^{\text {th }}$ June 1940. Those letters were about property like land/rubber plantation which

${ }^{22}$ Ahmadi, et al., Sejarah Jamaiyah, p. 4.

${ }^{23}$ The purpose of forming Tonarigumi was to improve the instruction and supervision of people. As stated in the news of forming, the purposes are "people try to improve their agricultural products and hand it over to the state". See in Marwati Djoened Poesponegoro and Nugroho Notosusanto, Sejarah Nasional Indonesia VI: Zaman Jepang dan Zaman Republik Indonesia, $2^{\text {nd }}$ ed, Revision Edition, (Jakarta: Balai Pustaka, 2008), p. 67.

${ }^{24}$ The term refers to forced labour, most of them are farmer, and since October 1943 the Japanese compulsory farmers became Romusha (work compulsively). Ibid., p. 67.

${ }^{25}$ Ahmadi, et al., Sejarah Jamaiyah, p. 18.

${ }^{26} I b i d .$, p. 18.

${ }^{27}$ Sultan Mahmud is the third Sultan or the last Sultan before the Social Revolution happened in 1946 in Langkat, East Sumatera. 
is located in Kampung Cempa, Hinai regency. ${ }^{28}$ But, because in 1942 Japan had dominated Indonesia including Langkat region, so automatically the development of madrasah halted and the number of students also reduced considerably. At the end of 1944, the fact was the number of students was really small, so the madrasah had to be closed temporarily while waiting for the war to cease. ${ }^{29}$

\section{Infrastructures}

As an initial step, Sultan donated one of his palaces, located in Kampung Dalam, Tanjung Pura to be used as madrasah. That palace was quite big and it could accommodate totaling to 8 classrooms plus some rooms for other uses. So, for the first time, it could accommodate and teach 400 students. ${ }^{30}$ The building which had been donated by him was made of wood and rumbia (sago palm) as the roof, board as the floor. Because he had built his palace more magnificent and bigger that was positioned 400 meter from his former palace. This first madrasah was named Madrasah Maslurah after his queen's name, Tengku Maslurah binti Tengku Desan. ${ }^{31}$ Meanwhile, the organization also tried to accommodate the orphans to be educated and raised in a house which then became the second madrasah. That house was from a house of a Prince who also got opportunity to make his palace. He used that house as orphanage shelter and then as the place of the orphans to get education. ${ }^{32}$ Sultan donated coplanar of land which was in Kampung Dalam that was his former palace surrounding with an area 4.3 ha. This land was situated in the riverside of Batang Durian. On this land, the organization built better and permanent buildings for education which made Langkat famous. ${ }^{33}$

Sultan Abdul Aziz received a donation from the members and philanthropists, and collected fund amounted f.36.812,-, then in 1923, two-storey building was built with 12 classrooms. One year later, the building was ready to use and utilize as classroom and dormitory. This permanent building had two levels with a small hall sized 10x10 meter as the rest room and study room for students who stayed overnight in that dormitory. To build this building spent cost f.45.000,- which meant he had to add f.8.200,- for the establishment of the building. Therefore, this building was the result of many people's donation together with him for this educational institution. ${ }^{34}$

Through the existence of the dormitory, the learning opportunity for those who came

\footnotetext{
${ }^{28}$ See in Ahmadi, et al., Sejarah Jamaiyah, p. 18.

${ }^{29}$ Ibid., p. 18.

${ }^{30}$ Azmi, et al., Sejarah Organisasi, p. 68.

${ }^{31}$ Ahmadi, et al., Sejarah Jamaiyah, p. 4.

${ }^{32}$ Ibid.

${ }^{33} I b i d .$, p. 5.

${ }^{34} I b i d$., p. 8.
} 
from outside of Langkat increased so in that time, many children were received as students who originated from Riau, Jambi, Tapanuli, Palembang, West Borneo, and even from Malaysia. In that time H. Adam Malik - former vice president of Indonesia - ever learned and entered one of the classrooms in that madrasah. Because of the existence of this building, Jam'iyah had increased the condition of madrasah became having 22 classrooms and 12 rooms, in addition, there were 2 halls and an orphanage house, swimming pool, football field and others. All of the infrastructures were situated in madrasah area from the waqf land of Sultan. This area of madrasah is positioned near area of Mosque Azizi so that the madrasah did not need to build a musala (small building to perform religious duties). While, the hall was utilized as the place of students gathering, tabligh (religious meeting), and for oral imtih1ân (testing people's positions on scholars), except utilized as the place of prayer exercise for beginner class in daily. ${ }^{35}$ In addition, this institution already had sport facilities such as football field with standard size and located in the field of madrasah, badminton court and its equipment. ${ }^{36}$

Before the World War II, the number of classroom according to educational level could be described as follows:

a. Tajhiziyah level (kindergarten)

At this stage, the learning period was 4 years with a total class was 18 classrooms with details of 12 classrooms for men and 6 classrooms for women with available time such as; morning class was for grade I and II. While, for grade III and IV could study at noon with details 12 classrooms for men and 6 classrooms for women, so the total classrooms was 36 rooms. ${ }^{37}$

b. Ibtidaiyah level (elementary school)

At this stage, classroom was provided as many as 12 rooms for men and 8 rooms for women, with learning time was in the morning and at noon. At this stage, students took 4 years to study. ${ }^{38}$

c. Tsanawiyah level (junior high school)

At this stage, there were 4 classrooms for men and 4 classrooms for women and learning schedule was only in the morning. For this level, students took 4 years to study. ${ }^{39}$

d. Qismul 'Alî or Takhassus level (Senior High School)

At this stage, there were only 2 classrooms for men, while there was no classroom for women. ${ }^{40}$

${ }^{35}$ Azmi, et al., Sejarah Organisasi, p. 69.

${ }^{36}$ Ahmadi, et al., Sejarah Jamaiyah, p. 10-11.

${ }^{37}$ Abdul Kadir Ahmadi and Zainal Arifin AKA, Jamaiyah Mahmudiyah Setelah 100 Tahun (Medan: Mitra, 2013), p. 54.

${ }^{38}$ Ahmadi, et al., Sejarah Jamaiyah, p. 14.

${ }^{39}$ Ibid., p. 14.

${ }^{40}$ Azmi, et al., Sejarah Organisasi, p. 70. 
From the illustration, it could be concluded that the number of classrooms got decreasing from Tajhizi level to Takhassus level. There were some things that caused this happened, such as:

a. Many students of Jam'iyah Mahmudiyah who had graduated from Tajhiziyah level continued their study to Ibtidaiyah level in public school like ELS (Europese Logare School). ${ }^{41}$ Likewise from Ibtidaiyah level to Tsanawiyah level, some of the students continue their study in public school like MULO (Meer Uitgereid Lager Onderwijs), for instance, Tengku Amir Hamzah, his study began after he finished his school in Tanjung Pura when he was 7 years old, he was sent by his parents to MULO in Medan from August 1925 to July 1928. After one year in Medan, he moved to MULO in Jakarta when he was 17 years old. After graduating from MULO in Jakarta, he continued his study in A.M.S majoring Eastern in Solo. ${ }^{42}$ This thing became the main cause of decreasing the number of students in Madrasah Jam'iyah Mahmudiyah Tanjung Pura, Langkat.

b. Many students of Jam'iyah Mahmudiyah who came from outside of Langkat, such as Medan, Asahan, Tapanuli, Padang, Aceh, Riau or even Malaysia. When they finished their study from Tajhizi, Ibtidaiyah, or Tsanawiyah level, they went back to their hometown so that they could continue their study in their hometown. ${ }^{43}$ This thing also was the main reason of lessening the quantity of students in Madrasah Jam'iyah Mahmudiyah Tanjung Pura, Langkat.

c. From the perspective of intellectual ability, women were only able to reach education until Tsanawiyah level, the women who were able to reach this stage could be claimed as smart women. Generally, women were only able to study until Ibtidaiyah level, if they could be at Tsanawiyah level, those are educated women. ${ }^{44}$ For instance, a woman who reached Tsanawiyah level was Hj. Khadijah (Umi Antik) binti Syaikh H. Abdur Rahim Abdullah. ${ }^{45}$

One thing that is considered as a pride of this madrasah was when it had a library as the infrastructure of reading activity which provided classic books that would be learned in it, reading book and others totaling to 8000 titles of books. ${ }^{46}$ Based on the historical facts, the existence of this library is true, because in the Langkat Sultanate era there was a printing machine. Master teacher Syaikh Abdul Wahab Rokan got a help in the form of waqf from

\footnotetext{
${ }^{41}$ Fakhruddin Ry (84 years old), a Historian from Langkat, interviewed in Stabat, on $5^{\text {th }}$ December 2016.

${ }^{42}$ Husin, Tengku Amir, p. 3.

${ }^{43}$ Fakhruddin Ry (84 years old), a Historian from Langkat, interviewed in Stabat, on $5^{\text {th }}$ December 2016.

${ }^{44}$ Fakhruddin Ry (84 years old), a Historian from Langkat, interviewed in Stabat, on $5^{\text {th }}$ December 2016.

${ }^{45}$ Azmi, et al., Sejarah Organisasi, p. 142.

${ }^{46}$ Ahmadi, et al., Sejarah Jamaiyah, p. 11.
} 
Sultan Langkat amounted to 2500 rupiah. Then, through $\mathrm{H}$. Bakri, a printing unit was bought which the intertype was Arabic letters. In 1326/1908 the printing was led by H. Bakri, H.M. Ziadah and H.M. Nur. ${ }^{47}$ At that moment, people were eager to deepen religious knowledge from Islamic books, in this case Master teacher Babussalam Syaikh Abdul Wahab Rokan had published and printed many books having theme Islamic issues, entitled: Aqîdah al-Islâm book, Kitab Sifat Dua Puluh (book of twenty attributes), Âdab al-Zaujain and many more.

\section{The Budgetting}

Jam'iyah Mahmudiyah had very good financial support when Sultan Langkat held the power. As the source of fund, Sultan gave monthly donation for the teachers' wages and earnings and also the tools that it needed. Sultan gave waqf of two shops located in Pekan Tanjung Pura, and the number of shops' unit got increased. In the end, Jam'iyah Mahmudiyah had 18 units of shop as the source of education budget. All of the shops had been donated as waqf, so madrasah could get the benefits of it for supporting the education. ${ }^{48}$

The owned shops were 14 doors located in Tanjung Pura with the number of king grant No. 67, 80, 84, 184, 186, 188, 190, 217, 219, 229, 285, 287, 315, and 317. Then, 2 doors are located in the center of Binjai town with grant no.77 and 156, in Stabat also had been donated or waqf 2 doors with grant No. 109 and others. ${ }^{49}$ For supporting this event, Jam'iyah provided source of funds that are considered sufficient, as had been mentioned above, those are: ${ }^{50}$

1. The shops which have 18 doors are located in Tanjung Pura town, Stabat and Binjai.

2. Sultan had waqf a coplanar of rubber garden with an area 25 ha which is ready to work on so the result could lighten the operational cost of educational process in madrasah.

3. A philanthropist, who does not want to be mentioned, had waqf a coplanar of land containing coconuts with an area 1ha which is located in Pematang Serai village, Tanjung Pura.

4. The donation from the members of Jam'iyah.

5. In the period of Japanese occupation, the budget was collected from students' dues. Because the number of students got decreasing, even female students were not there at all for fear of leaving house. As the result, many teachers did not teach and got no salary. ${ }^{51}$

\section{The Contents of Education}

The contents of education in Jam'iyah Mahmudiyah mostly imitates what Al-Azhar

\footnotetext{
${ }^{47}$ See in Said, Syaikh A. Wahab, p. 100.

${ }^{48} \mathrm{Ahmadi}$, et al., Sejarah Jamaiyah, p. 5.

${ }^{49}$ Ibid., p. 5.

${ }^{50}$ Ibid., p. 11.

${ }^{51}$ Ahmadi, et al., Sejarah Jamaiyah, p. 18.
} 
and Dâr al-'Ulûm, Egypt, have. It was clearly seen after students, who were sent to both Universities, came back to Langkat. It is stated in Principal Law of al-Azhar in 1872, subjects that are taught in the class are ushul fiqh (the origin of Islamic law), fiqh (study of Islam law), tauhîid (divinity), hadîts (Prophet's utterance), tafsîr (translation), nahw (grammar), alsharf (morphology), ma'anî (semantics), bayân (semantics), badi' (literature), and mantiq (logics). ${ }^{52}$ Previously, the content imitated what Mosque Al-Haram, Mecca, had. Even religious subjects are the main subjects, common subjects are the inseparable part in this school. ${ }^{53}$

Arabic letter was used in the daily teaching-learning process, therefore, all subjects used Arabic, Ibtidaiyah and Tsanawiyah levels used Arab gundul (Arabic script without diacritical marks). Then, students were given some particular subjects practically such as Tahlil, Tahtim, Marhaban, Barzanji, Du'a, leading Shalat (Imam), and Khatib (sermoner). ${ }^{54}$

The selection of textbook for students and teacher was conducted carefully, beside the teaching method should be good and appropriate. Therefore, learning materials were arranged based on the level of education, including textbooks used in the class as the followings:

\section{Tajhiziyah Level}

Bahasa Indonesia in this level is used orally as the medium of teaching in the class, but written in Arabic letter. Subjects and textbooks that are used in this level are:

Table 1

Content of Education for Tajhiziyah (Kindergartern and Primary) Level ${ }^{55}$

\begin{tabular}{|c|l|l|l|}
\hline No. & \multicolumn{1}{|c|}{ Subjects } & \multicolumn{1}{c|}{ Title of textbooks } & \multicolumn{1}{c|}{ Authors } \\
\hline 1 & Hijaiyah/ Arabic letters & Alquran & Teacher's policy \\
\hline 2 & $\begin{array}{l}\text { Keimanan-Tauhîid/ } \\
\text { Divinity }\end{array}$ & Kitab Tauhîid & Not found \\
\hline 3 & Ibadah-Fiqih & Kitab Fikih Melayu & Not found \\
\hline 4 & $\begin{array}{l}\text { Translation of Quran } \\
\text { verse. }\end{array}$ & Alquran terjemah & Teacher's policy \\
\hline 5 & $\begin{array}{l}\text { Translation of Hadith } \\
\text { Mutawatir }\end{array}$ & $\begin{array}{l}\text { Terjemahan Hadis } \\
\text { Mutawatir }\end{array}$ & Teacher's policy \\
\hline 6 & Al-Tajwîd & $\begin{array}{l}\text { Hidâyah al-Shibyân fî̀ } \\
\text { Ma'rifah al-Islâm wa al- } \\
\text { Imân, versi Jawi. }\end{array}$ & $\begin{array}{l}\text { Abu 'Abdullâh Húnain Nâshir } \\
\text { Bin Muhamammad Thayyib al- } \\
\text { Sa'ûdî al-Banjârî }\end{array}$ \\
\hline
\end{tabular}

${ }^{52}$ Muhammad 'Abd al-Mun'im Khafaji, Al-Azhar fi Alfi 'Âm, Edition. 2 (al-Qahirah: Maktabah al-Kulliyyât al-Azhariyah, 1988), p. 175.

${ }^{53}$ Ahmadi, et al., Sejarah Jamaiyah, p. 11-12.

${ }^{54}$ Ahmadi, et al., Sejarah Jamaiyah, p. 12.

${ }^{55}$ Ahmadi dan Arifin AKA, Jamaiyah Mahmudiyah, p. 54. 
Zaini Dahlan: Islamic Education During Langkat Sultanate Era in 1912-1942

\begin{tabular}{|c|l|l|l|}
\hline 7 & $\begin{array}{l}\text { Al-Târîkh/ history of } \\
\text { Prophets and Islam }\end{array}$ & $\begin{array}{l}\text { Nûr al-Yaqîn fí Shirah } \\
\text { Sayyid al-Mursalîn }\end{array}$ & $\begin{array}{l}\text { Syaikh Muhammad al- } \\
\text { Hudhari Bik }\end{array}$ \\
\hline 8 & Lughah 'Arab & Al-Lugah al-'Arabiyah & Teacher's policy \\
\hline 9 & Naḩwu/ Grammar & Matn Jurûmiyah & $\begin{array}{l}\text { Abu 'Abdillâh Muhammad } \\
\text { bin Muhammad bin Dâwûd } \\
\text { al-Shinhâji, }\end{array}$ \\
\hline 10 & Tashrîf & Matan al-Binâ' wa al-Asâs & Imâm Malâ 'Abdullâh \\
\hline 11 & Imla'/ writing Arabic & Al-Lugah al-'Arabiyah & Teacher's policy \\
\hline 12 & $\begin{array}{l}\text { Reading and Writing } \\
\text { Latin }\end{array}$ & No textbook & Teacher's policy \\
\hline 13 & Geography & Ilmu Bumi, Bahasa Melayu & Teacher's policy \\
\hline 14 & Biology-Plants & $\begin{array}{l}\text { Ilmu Tumbuh-tumbuhan, } \\
\text { Bahasa Melayu }\end{array}$ & Teacher's policy \\
\hline 15 & Biology-Animals & $\begin{array}{l}\text { Ilmu Hewan, Bahasa } \\
\text { Melayu }\end{array}$ & Teacher's policy \\
\hline 16 & Math-Counting & Berhitung, Bahasa Melayu & Teacher's policy \\
\hline 17 & Tahtim and Tahlil & Buku Tahtim dan Tahlil & Teacher's policy \\
\hline 18 & $\begin{array}{l}\text { Barzanji and } \\
\text { Marhaban }\end{array}$ & Maulîd al-Barzanjî & $\begin{array}{l}\text { Syaikh Zainal 'Âbidîn Ja'far } \\
\text { bin Hasan bin 'Abd al-Karîm } \\
\text { al-Husuini asy-Syahrazuri, }\end{array}$ \\
\hline 19 & Salat-Practice & No textbook & Teacher's policy \\
\hline 20 & Gymnastic & No textbook & Teacher's policy \\
\hline 21 & Akhlak (Ethics) & Buku Akhlak & Teacher's policy \\
\hline 22 & Calligraphy & No textbook & Teacher's policy \\
\hline
\end{tabular}

By looking at the subjects in this level, it was commonly found that there was a collaboration of naqliyah science (sciences based on Al-Quran and Sunnah) and aqliyah science (sciences based on logics and rational), but perhaps the percentage of naqliyah (70\%) is higher than aqliyah (30\%). The percentage of common subjects and religious subjects was different in each madrasah. Some put $30 \%$ for common subjects, but some others put $40 \%$ or even $50 \% .{ }^{56}$ For instance, Kulliyah Mu'allimat Islamiyyah that has been established since February $1^{\text {st }} 1937$, put $40 \%$ for common subjects. ${ }^{57}$ It is necessary to comprehend that although religious subjects were the main subjects, common subjects couldn't be ignored easily as the aim of Sultan to prepare all students who had graduated from this school became religious and people leaders in their society. ${ }^{58}$

\section{Ibtidaiyah Level}

The discussion of religious subjects taken were deeper than the previous level and all

${ }^{56}$ Yunus, Sejarah Pendidikan, p. 102-103.

${ }^{57}$ Yunus, Sejarah Pendidikan, p. 102-103.

${ }^{58}$ Ahmadi, et al., Sejarah Jamaiyah, p. 11. 
MIQOT Vol. XLI No. 1 Januari-Juni 2017

textbooks use Arabic even some of them still had line on it. Subjects and textbooks that were used in this level are:

Table 2

Content of Education for Ibtidaiyah ${ }^{59}$

\begin{tabular}{|c|c|c|c|}
\hline No. & Subject & Title of book & Author \\
\hline 1 & Tauhîd/ divinity & $\begin{array}{l}\text { Matan al-Sanusiyyah al- } \\
\text { Kubra } \\
\text { Kifâyah al-'Awâm }\end{array}$ & $\begin{array}{l}\text { Abu Abdillâh Muhammad bin } \\
\text { Yûsuf al-Sanusi } \\
\text { Syaikh Muhammad Ibn al- } \\
\text { Syâfi'î al-Fudhlaliy al-Syâfi'î }\end{array}$ \\
\hline 2 & Tafsîr/ translation & Tafsîr Jalâlaîn & $\begin{array}{l}\text { Jalâl ad-Dîn Al-Mahalli dan } \\
\text { Jalâl ad-Dîn al-Suyûthî }\end{array}$ \\
\hline 3 & Fiqh & $\begin{array}{l}\text { Matn Gayât wa al-Taqrîb } \\
\text { Fath al-Qarîb al-Mujib fî } \\
\text { Syarh Alfâzh al-Taqrîb }\end{array}$ & $\begin{array}{l}\text { Syihabuddîn Abu Syujâ' Al- } \\
\text { Ashfahâni } \\
\text { Abu Abdullâh Syamsuddîn } \\
\text { Muhammad bin Qâsim bin } \\
\text { Muhammad al-Gazzî al-Syâfi'î, }\end{array}$ \\
\hline 4 & Akhlâq & Taisîr al-Khallâq & Hâfiz Hasan Al-Mas'ûdî \\
\hline 5 & $\begin{array}{l}\text { Nahw/ Arabic } \\
\text { Grammar }\end{array}$ & $\begin{array}{l}\text { Nahww al-Wâdhih fí Qawấid } \\
\text { al-Lugah al-Arabiyyah }\end{array}$ & $\begin{array}{l}\text { 'Ali al-Jarimî dan Mushthafâ } \\
\text { Amîn }\end{array}$ \\
\hline 6 & Sharf/ Morphology & Syarh al-Kailâni & Syaikh ‘Ali Hisyam al-Kailâni \\
\hline 7 & Manthiq/ Logics & 'Ilm al-Manthiq & Muhammad Nûr al-Ibrâhîmî \\
\hline 8 & Bayân/ Semantics & Not found & Not found \\
\hline 9 & $\begin{array}{l}\text { Hadîṫ́s Prophet's } \\
\text { utterance }\end{array}$ & Sunan Ibn Majâh & $\begin{array}{l}\text { Imâm Abu Abdullâh } \\
\text { Muhammad bin Yazid bin } \\
\text { Majâh al-Râbi'i al-Qarwinî }\end{array}$ \\
\hline 10 & $\begin{array}{l}\text { Mushthalah Hadîts/ } \\
\text { Discussion of } \\
\text { Prophet's utterance }\end{array}$ & Minhah al-Mugiś & $\begin{array}{l}\text { Hafîz Hasan al-Mas'udi } \\
\text { Muhammad az-Zuqani }\end{array}$ \\
\hline 11 & Tarîkh/ History & $\begin{array}{l}\text { Nûr al-Yaqîn fi Shirah } \\
\text { Sayyid al-Mursalîn }\end{array}$ & $\begin{array}{l}\text { Syaikh Muhammad Al-Hudhari } \\
\text { Bik }\end{array}$ \\
\hline 12 & Muthala'ah/ Syntax & Qira'ât al-Rasyîdah & $\begin{array}{l}\text { Syaikh 'Abd al-Fattâh dan } \\
\text { Syaikh 'Alî 'Umar }\end{array}$ \\
\hline 13 & $\begin{array}{l}\text { Muhadasât/ } \\
\text { Conversation }\end{array}$ & No textbook & Teacher's policy \\
\hline 14 & $\begin{array}{l}\text { Insyâ' Arab and } \\
\text { Imlâ'/ writing }\end{array}$ & Al-Lugah al-'Arabiyah & Teacher's policy \\
\hline 15 & $\begin{array}{l}\text { Mahfuzhât/ Arabian } \\
\text { aphorisms }\end{array}$ & Not found & Teacher's policy \\
\hline
\end{tabular}

${ }^{59}$ Ibid., p. 14-15. 


\begin{tabular}{|c|l|l|l|}
\hline 16 & $\begin{array}{l}\text { Ushûl Fiqh/ The } \\
\text { Origin of Islamic law }\end{array}$ & Waqarât fí Ushûl Fiqh & $\begin{array}{l}\text { 'Abd al-Mâlik bin Abdullâh } \\
\text { bin Yûsuf bin Muhammad bin } \\
\text { Hayyuyah Al-Juwainî As- } \\
\text { Sanbasî al-Tha'î al-Naisaburî } \\
\text { Al-Syâfi'î }\end{array}$ \\
\hline 17 & Math/ Hisab & $\begin{array}{l}\text { Gemar Berhitung, Jilid I } \\
\text { dan II }\end{array}$ & J. Bijl \\
\hline 18 & Geography & Not Found & Not Found \\
\hline 19 & Sports & No Textbook & Teacher's policy \\
\hline 20 & Sanitary & Not Found & Not Found \\
\hline 21 & Cosmography & Not Found & Not Found \\
\hline 22 & Arts & Not Found & Teacher's policy \\
\hline 23 & Malay Language & Not Found & Teacher's policy \\
\hline 24 & $\begin{array}{l}\text { Balagah/ Socio- } \\
\text { linguistics }\end{array}$ & $\begin{array}{l}\text { Matn Jauhar al-Makmûn } \\
\text { (al-Ma'ânî) }\end{array}$ & Muhammad al-Khudhari Bik \\
\hline 25 & Arabian Caligraphy & $\begin{array}{l}\text { Khat Naskh, Ri'qah, Menulis } \\
\text { Indah }\end{array}$ & Teacher's policy \\
\hline
\end{tabular}

All subjects stated above were taught in Bahasa Indonesia, while textbook used and discussed by students are in Arab gundul. In this level, the discussion about Arabic sentences was started by enriching and sharpening Nahwu and Sharaf (Arabic Grammar and Morphology). In Ibtidaiyah level, the percentage of naqliyah was $70 \%$ while aqliyah was $30 \%$. However, it is interesting that Math/hisab had been taught in this school. Imam al-Syâfi'îy asserts:

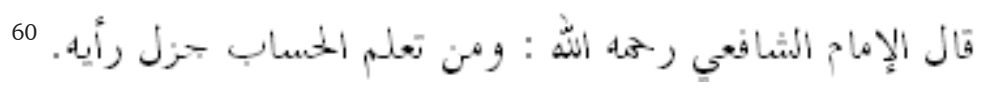

Imâm Syâfiî says: "and whoever learns Mathematics, he has strong argument."

Based on Imâm Syâfi'î’s opinion, the advantage of learning math/hisab is strengthening the arguments for whoever learns it. Therefore, math/hisab is necessary to be learnt to support faraid (science of dividing inheritance). ${ }^{61}$

\section{Tsanawiyah Level}

The discussion for knowledge in this level is taught deeply, especially in Alat science (such as nahwu, sharaf, bayan, badi'). All textbooks were in Arab gundul and those textbooks are syarah (the discussion edition of the origin book). Here are the subjects and textbooks that are used:

${ }^{60} \mathrm{Abu}$ al-Hasan 'Alî ibn Muhammad ibn al-Basharî al-Mâwardî, Adab al-Dunyâ wa al-Dîn, $3^{\text {rd }}$ ed. (Surabaya: Syirkah Bongkol Indah, t.t.), p. 45-46.

${ }^{61}$ Abdul Mukti, "Prinsip-Prinsip Pembelajaran dalam Islam," in Al Rasyidin (ed.), Wacana Pemikiran Pendidikan Islam (Bandung: Citapustaka Media, 2012), p. 2. 
Table 3

Content of Education for Tsanawiyah (Junior High School) ${ }^{62}$

\begin{tabular}{|c|c|c|c|}
\hline No. & Subject & Title of textbook & Author \\
\hline 1 & Tafsîr/ translation & $\begin{array}{l}\text { Tafsir Jalâlaîn } \\
\text { Shafwah al-Tafâsîr }\end{array}$ & $\begin{array}{l}\text { Jalâl ad-Dîn Al-Mah̄alli dan Jalâl } \\
\text { ad-Dîn al-Suyûthî } \\
\text { Muhammad 'Alî Ibn Jamîl al- } \\
\text { Shabûnî }\end{array}$ \\
\hline 2 & Tauhîid/ divinity & $\begin{array}{l}\text { Hêasyiyah al-Dasûqî̀ 'ala Syarh } \\
\text { 'Umm al-Barahîn }\end{array}$ & $\begin{array}{l}\text { Syaikh Muhamamad ibn Ahmad } \\
\text { al-Dasûqî }\end{array}$ \\
\hline 3 & Fiqh & $\begin{array}{l}\text { Hâasyiyah al-Bajurî Syarh } \\
\text { Matn Gayât wa al-Taqrîb } \\
\text { Mugnîy al-Muhtaj }\end{array}$ & $\begin{array}{l}\text { Burhânuddîn Ibrâhîm al-Bajurî } \\
\text { bin Syaikh Muhammad al-Jizawi } \\
\text { bin Ahmad } \\
\text { Syamsuddîn Muhamammad bin } \\
\text { Ahnmad al-Khatîb al-Syarbainî }\end{array}$ \\
\hline 4 & Hadîts & $\begin{array}{l}\text { Al-Jâmi' al-Musnad al-SHahîhh } \\
\text { al-Mukhtashar min Umur } \\
\text { Rasûlullâh Shallâllâhu 'Alaihi } \\
\text { Wasallam wa Sunanihi. }\end{array}$ & Imâm Bukhârî \\
\hline 5 & Ushûl Fiqh & $\begin{array}{l}\text { Nihâyatus Sûl fi Syarhi Minhâj } \\
\text { al-Wushûl ilâ 'Tlmi Ushûl }\end{array}$ & $\begin{array}{l}\text { Jamaluddîn Abdurrahîm bin al- } \\
\text { Hasan Al-Isnawi }\end{array}$ \\
\hline 6 & Tasawuf/ Sufism & Books of Tarikat Naqsyabandiy & Not Found \\
\hline 7 & Farq al-Islâmiyah & Not Found & Not Found \\
\hline 8 & $\begin{array}{l}\text { Tarîkh Islâm/ } \\
\text { History of Islam }\end{array}$ & Not Found & Not Found \\
\hline 9 & $\begin{array}{l}\text { Ilmu Tafsîr/ } \\
\text { Discussion of } \\
\text { translation }\end{array}$ & Not Found & Not Found \\
\hline 10 & $\begin{array}{l}\text { Ushûluddîn/ the } \\
\text { Nature of Islam }\end{array}$ & Not Found & Not Found \\
\hline 11 & $\begin{array}{l}\text { Nahw/ Arabic } \\
\text { Grammar }\end{array}$ & Hâsyiyah al-Khudharî & al-Khudharî \\
\hline 12 & Sharf/ Morphology & Syarh al-Kailânî & Syaikh 'Ali Hisyam al-Kailânî \\
\hline 13 & Bayân/ Semantics & $\begin{array}{l}\text { Nadham Jauhar Maknûn fî } \\
\text { Salâsah al-Funûn }\end{array}$ & $\begin{array}{l}\text { Syaikh 'Abd al-Rahman al- } \\
\text { Akhdarî }\end{array}$ \\
\hline 14 & $\begin{array}{l}\text { Badi'/ Literature } \\
\text { or Poetry }\end{array}$ & Not Found & Not Found \\
\hline 15 & Balaghah & Qawấid al-Lugah al-'Arabiyah & Hadharat Hafni Bîk \\
\hline 16 & Manthiq/ Logics & 'Ilm al-Mathiq & Muhammad Nûr al-Ibrâhîmî \\
\hline 17 & Ma'ani/ Semantics & Not Found & Not Found \\
\hline 18 & Arudh/ Wisdom & Not Found & Not Found \\
\hline
\end{tabular}

${ }^{62}$ Ahmadi, et al., Sejarah Jamaiyah, p. 14-15. 
Zaini Dahlan: Islamic Education During Langkat Sultanate Era in 1912-1942

\begin{tabular}{|l|l|l|l|}
\hline 19 & $\begin{array}{l}\text { Faraid/ Science of } \\
\text { dividing } \\
\text { inheritance }\end{array}$ & Matn ar-Rahbiah & Muhammad ar-Raḩbi \\
\hline 20 & Adâbul Bahâś & Not Found & Not Found \\
\hline 21 & Mushthalâh Hadîts & Minhah al-Mugits & $\begin{array}{l}\text { Hafîz Hasan al-Mas'udi } \\
\text { Münmad az-Zuqani }\end{array}$ \\
\hline 22 & Geography & Not Found & Not Found \\
\hline 23 & Hisab/ Math & Not Found & Not Found \\
\hline 24 & $\begin{array}{l}\text { Insyâ' and Ilmu } \\
\text { Falak/ writing } \\
\text { and cosmography }\end{array}$ & Not Found & Not Found \\
\hline 25 & $\begin{array}{l}\text { Tarîkh Tamaddûn } \\
\text { Islâm/ History of } \\
\text { Islamic civilization }\end{array}$ & Not Found & Not Found \\
\hline 26 & $\begin{array}{l}\text { Technique of public } \\
\text { speaking and } \\
\text { speech }\end{array}$ & No textbook & Teacher's policy \\
\hline 27 & Sports & No textbook & Teacher's policy \\
\hline
\end{tabular}

In Tsanawiyah level, the percentage of naqliyah is 70\% while aqliyah has 30\%. However, the main concern is there are so many reference books used by Tajhiziyah, Ibtidaiyah, or Tsanawiyah that had vanished so that the researcher had difficulty in stating the title of the book as well as the author. It is because the library of Jam'iyah Mahmudiyah and personal library of the teachers who graduated from Al-Azhar, Mecca/Medina, even domestic were destroyed by Japanese soldiers, NICA, and Poh An Tui in the first military aggression of Netherland on July $21^{\text {st }} 1947$ to August $5^{\text {th }} 1947$ and in second aggression on December $19^{\text {th }} 1948 . .^{63}$

\section{Qismul ‘Alî (Takhassus)}

In this level, all subjects were the same as Tsanawiyah level but it took deeper discussion, so that every single sentence in their textbook should be understood clearly together with its function and meaning. Meanwhile, some subjects were taught through practice and training. Sometimes students were required to hold a discussion or presentation, so that it could be clear enough for the teacher to know that students did comprehend the subject. ${ }^{64}$ This tradition had been held in Jam'iyah Mahmudiyah since 1892. At that time, Syaikh Muhammad Ziadah as the Head Master of Madrasah Maslurah Lilbanat and Madrasah Mahmudiyah Lilbanin used to advise his students to use their break time to hold a discussion in a classroom or old Mosque-since Mosque Azizi had been completely constructed, the $5^{\text {th }} 2016$.

${ }^{63}$ Fakhruddin Ry (84 years old), a Historian of Langkat, interviewed in Stabat, December

${ }^{64}$ Azmi, et al., Sejarah Organisasi, p. 70. 
old Mosque became house for suluk. ${ }^{65}$ By applying this method, it aroused the enhancement of students' motivation to study and sharpen their arguments, but it was limited, no group discussion was made because there should be a teacher directing the discussion. ${ }^{66}$ Additionally, the teachers assigned to direct the discussion were not only from domestic teachers, but also from foreign teachers such as from Saudi Arabia, such as Syaikh Abdurrahman, Said Ahmad, Said Abu Bakar, dan Ibrahim Al-Hindy. ${ }^{67}$

Test would be given in each level as a sign of finishing that level itself. For the level of Tajhiziyah and Tsanawiyah, test would be given through two ways, namely written and spoken or oral test. Oral test would be conducted on school hall that was usually attended by religious leaders if they were available, and officials of the country or Sultanate. The examiners are usually senior teachers, ulama, and officials of the Sultan Palace. Qadhi or mufti of Sultanate would also attend the examination and gave some questions that had to be answered by imtih1ân (the test taker). There were only three subjects that would be examined orally. They are Tafsir, Fiqh, and Tauhid. Each Mumtahîn (the examiners) would give the test takers' score that would be counted so that the average score would be obtained. If the score fulfills the passing grade, then the student would pass the level and would be granted a license/certificate. Each student should have possessed all these licenses to follow the final test. ${ }^{68}$ It was difficult to get the graduated license in that era, proved by final test for the first time in 1915, there were 40 students taking the test but only 15 students passed. The rest had to take the test from the previous level. ${ }^{69}$

Beside all activities stated above, Jam'iyah also published a magazine released once a month named "Bintang Islam". This magazine was in the same era with magazine "Dewan Islam" published in Medan by Abd. Rahman Syihab dan Muhammad Arsyad Thalib Lubis. Sultan had fully supported this magazine so that it had lasted for many years until the World War II happened. Customers of the magazine were controlled by the officials of the Country, the Great Men but the chief editor and the authors itself were the young teachers and also students who were talented in writing. As this magazine took on behalf of Jam'iyah Mahmudiyah, therefore the leader of Jam'iyah had been directly responsible for this magazine. ${ }^{70}$

\section{The Teachers and Students}

Handled by the best teachers in their field, Jam'iyah Mahmudiyah developed to be great organization. It was proved by the teachers who had background of education from Ummul

${ }^{65}$ Fakhruddin Ry (84 years old), a Historian from Langkat, interviewed in Stabat, December $10^{\text {th }} 2016$.

${ }^{66}$ Ibid.

${ }^{67}$ Azmi, et al., Sejarah Ulama, p. 57.

${ }^{68}$ Ibid., h. 69.

${ }^{69}$ Ahmadi, et al., Sejarah Jamaiyah, p. 9.

${ }^{70}$ Ibid., p. 17. 
Qurâ' and Al-Azhar that had been asked their willingness in honor to teach on Sultanate Palace of Langkat since 1892 then after Jam'iyah Mahmudiyah was built, those sophisticated ulama started teaching in some schools. ${ }^{71}$ There were some great ulama in Tanjung Pura Langkat that had been proclaimed as teaching staffs in the Palace by Sultan. They were Syaikh H. Muhammad Yusuf Gelar Tok Engku, Syaikh H. Abdul Wahab Rokan (1230/1811-1345/ 1926), and H. Muhammad Nur Langkat bin H. Ismail (1926/1879-1362/1943). ${ }^{72}$

Besides that, through the initiative of the leaders of Jam'iyah Mahmudiyah Langkat and also the kindness of Sultan Langkat, some of the best students of Langkat region were gradually sent to study in these two universities in order to increase the quality of education in Jam'iyah Mahmudiyah. The first batch in 1922, some students were sent including Tuan Syaikh H. Muhammad Ziadah, Syaikh H. Abdullah Afifuddin, and Tuan Syaikh H. Abdul Rahim Abdullah or Abuya. ${ }^{73}$ Then, in 1924, H. Tengku Yafizham, H. Abd. Hamid Zahid, H. M. Salim Fachri, H. O.K. Salamuddin, H. Ibrahim Abdul Halim, H. Ahmad Dahlan, and H. Mahmud Yunus were also sent. ${ }^{74}$

Jam'iyah Mahmudiyah had accepted students not only from the low level but also from the middle one. This school had not only accepted students from Sultanate families, but also all society level that had willingness in seeking knowledge. Even, this school had also opened the opportunity for the orphans to study. This school was only for the descendants of the king and nobles in the beginning, however in its development, since 1892, this school had opened the chance for everyone to learn and study in this school. It was not only boys but also girls allowed to enroll. This school would accept every child who had come whether they could read and write or not. For those who could not read and write, they would be educated, guided, and nurtured in this school. ${ }^{75}$

The minimum criterion to be a student of Jam'iyah Mahmudiyah is they should have been 6 years old or more. Steenbrink's holds that children should be between 6 to 10 years old to start learning about Al-Qur'an. ${ }^{76}$ There is no any age limitation for the higher level. Students could enroll to the higher level only if they had basic previous knowledge proved by the license or certificate. Students of Jam'iyah Mahmudiyah were not only from Langkat, but also from other areas even overseas, for instance, in East Sumatera such as Langkat, Medan, Asahan, Tapanuli, Riau, Jambi, Aceh/Langkat Tamiang, Aceh Timur, and Simalungun.

\footnotetext{
${ }^{71}$ Religious teachers those come from Ummul Qurâ' (Mecca) and al-Azhar (Egypt), are Syaikh Ahmad Bukur, Syaikh Abdur Rahman, Syaikh Ahmad, and Syaikh Ibrahim Al-Hindi. see Azmi, et al., Sejarah Ulama, p. 3.

${ }^{72}$ Ibid., p. 28.

${ }^{73}$ Azmi, et al., Sejarah Organisasi, p. 70.

${ }^{74}$ Ibid., p. 71.

${ }^{75}$ Ahmadi, et al., Sejarah Jamaiyah, p. 6-7.

${ }^{76}$ Karel A. Steenbrink, Pesantren Madrasah Sekolah: Pendidikan Islam dalam Kurun Modern, $2^{\text {nd }}$ ed (Jakarta: LP3S, 1994), p. 11.
} 
And those who came from outer Sumatera are from West Borneo, Malaysia, Brunei Darussalam, and Pattani, (South Thailand). ${ }^{77}$ Sultan Langkat had prepared a dormitory for out of town students.

\section{Management}

As an educational institution that was built during the Langkat sultanate era, so all kinds of management of the education were directly controlled by an organization supervised by Sultan Langkat (Janab al-'Alî). It was marked by an official announcement and an establishment of a social and educational organization named "Jam'iyah Mahmudiyah Li Thalibil Khairiyah" that has meaning "an honorable association to reach worthiness". The official letter was issued by Sultan with note No. 120 year 1912 on 22 Muharram 1330 or December $31^{\text {st }} 1912 .{ }^{78}$ Therefore, firstly, this is the organization that was directly established by Sultan Abdul Aziz based on all supports from ulama and Moslem society in Langkat that aims to direct Islamic education for all children who needed.

Jam'iyah Mahmudiyah supervised some educational institutions in the areas that were donated by Sultan Langkat. They are Madrasah Maslurah established since 1892, Madrasah Aziziyah established since 1914, and Madrasah Mahmudiyah established since 1921. ${ }^{79}$ In the next development, the management of these schools had been supervised/ controlled hereditarily by Jam'iyah Mahmudiyah Li Thalibil Khairiyah up to now.

\section{Conclusion}

From the elaboration in advance, the conclusions can be drawn that; first, Jam'iyah Mahmudiyah Li Thalibil Khairiyah is the first systematic, well-planned, modern, and formal institution of education in East Sumatera; second, viewed from organizational aspect, Jam'iyah Mahmudiyah has clear vision, mission, organizational structure, modern facilities and infrastructure, and financial. In 1912, Jam'iyah Mahmudiyah arranged a renewal in this organization. Test would be given in each level and certificate would be awarded to the students who had passed the level. All teachers in Jam'iyah Mahmudiyah were ulama who had graduated from Ummul Qurâ' and al-Azhar. Management of education was directly controlled and supervised by Sultan Langkat. Apparently the fate of this school followed the fate of the sultanate. The decline of Langkat Sultanate was soon followed by Jam'iyah Mahmudiyah. At present, Jam'iyah Mahmudiyah continues to play its role as Islamic education institution, but its contribution by no means camparable to that of its heyday.

\footnotetext{
${ }^{77}$ Azmi, et al., Sejarah Organisasi, p. 45.

${ }^{78} \mathrm{Ahmadi}$, et al., Sejarah Jamaiyah, p. 3.

${ }^{79}$ Azmi, et al., Sejarah Organisasi, p. 45.
} 


\section{References}

'Alî, Sa'îd Ismâ'il. Nasya'au al-Tarbiyah al-Islâmiyah. al-Qahirah: 'Alam al-Kutub, 1978.

Ahmadi, A. Kadir, et al. Sejarah Jamaiyah Mahmudiyah Li Thalabil Khairiyah Tanjung Pura Langkat Sumut. Langkat: Pengurus Besar Jamaiyah Mahmudiyah Li Thalabil Khairiyah Tanjung Pura, 1994.

Ahmadi, Abdul Kadir, dan Zainal Arifin AKA. Jam'iyah Mahmudiyah Setelah 100 Tahun. Medan: Mitra, 2013.

Al Rasyidin. "Islamic Organizations iIn North Sumatra: the Politics of Initial Establishment and Later Development," in Journal of Indonesian Islam, Volume 10, Number 1, June 2016.

Al-ㅂasan 'Abd. al-Tarbiyah al-Islâmiyah al-Qarn al-Râbi' al-Hijriy. Kairo: Dâr al-Fikr al'Arabiy, 1978.

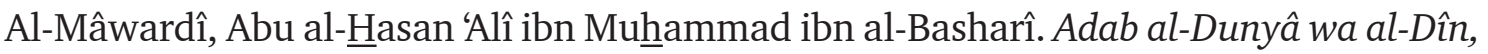
ed. 3, Surabaya: Syirkah Bongkol Indah, t.t..

Asari, Hasan. Menguak Sejarah Mencari 'Ibrah; Risalah Sejarah Sosial-Intelektual Muslim Klasik. Bandung: Citapustaka Media, 2006.

Asari, Hasan. Menyingkap Zaman Keemasan Islam: Kajian atas Lembaga-lembaga Pendidikan. Bandung: Citapustaka Media Perintis, 2013.

Asari, Hasan. Modernisasi Islam: Tokoh, Gagasan dan Gerakan. Bandung: Citapustaka Media, 2002.

Azmi, Fachruddin, et al. Sejarah Organisasi Pendidikan dan Sosial Jam'iyah Mahmudiyah Li Thalibil Khairiyah Tanjung Pura Langkat. Bandung: Citapustaka Media Perintis, 2012.

Azmi, Fachruddin, et al. Sejarah Ulama Langkat dan Tokoh Pendidik Jam'iyah Mahmudiyah Li Thalibil Khairiyah Tanjung Pura Langkat. Bandung: Citapustaka Media Perintis, 2012.

Azmi, Fachruddin, et al. Pengabdian Alumni Sepanjang Masa: Alumni Jam'iyah Mahmudiyah li Thalibil Khairiyah. Bandung: Citapustaka Media Perintis, 2012.

Azmi, Fachruddin. Jam'iyah Mahmudiyah li Thalibil Khairiyah dan Semangat Kebangsaan. Tanjung Pura: Speech of the chairman of PB JML at a big family of JML gathering in Syaikh Mohd. Ziadah's main hall, on 20 ${ }^{\text {th }}$ of August 2016.

Azra, Azyumardi. Islam in the Indonesian World: An Account of Institutional Formation. Bandung: Mizan, 2006.

Azra, Azyumardi. Jaringan Ulama Timur Tengah dan Kepulauan Nusantara Abad XVII dan XVIII: Akar Pembaruan Islam Indonesia. Jakarta: Kencana Prenada Media, 2005.

Daulay, Haidar Putra. Historisitas dan Eksistensi Pesantren, Sekolah dan Madrasah. Yogyakarta: Tiara Wacana, 2001.

Daulay, Haidar Putra. Sejarah Pertumbuhan dan Pembaruan Pendidikan Islam di Indonesia. Jakarta: Kencana Prenada Media, 2012. 
MIQOT Vol. XLI No. 1 Januari-Juni 2017

Hourani, Albert. Arabic Thought in the Liberal Age 1798-1939. London: Oxford University, 1962.

Husin, Djohar Arifin. Sejarah Kesultanan Langkat. Medan: Yayasan Bangun Langkat Sejahtera, 2013.

Khafaji, Muhammad 'Abd al-Mun'im. Al-Azhar fi Alfi ‘̂̂m, Vol. II. Al-Qahirah: Maktabah al-Kulliyyât al-Azhariyah, 1988.

Leedy, Paul D. Practical Research: Planning and Design. New York: McMillan Publishing Co, 1978.

Mukti, Abd. "Prinsip-Prinsip Pembelajaran dalam Islam," in Al Rasyidin (ed.), Wacana Pemikiran Pendidikan Islam. Bandung: Citapustaka Media, 2012.

Mukti, Abd. Konstruksi Pendidikan Islam: Belajar dari Kejayaan Madrasah Nizamiyah Dinasti Saljuq. Bandung: Citapustaka Media, 2007.

Mukti, Abd., "Sejarah Pertumbuhan dan Perkembangan Lembaga Pendidikan Islam di Indonesia," dalam Asnil Aidah Ritonga, (ed.), Pendidikan Islam dalam Buaian Arus Sejarah. Bandung: Citapustaka Media, 2008.

Poesponegoro, Marwati Djoened, dan Nugroho Notosusanto. Sejarah Nasional Indonesia VI; Zaman Jepang dan Zaman Republik Indonesia. Jakarta: Balai Pustaka, 2008.

Said, H. A. Fuad. Syaikh A. Wahab: Tuan Guru Babussalam, ed. 6. Medan: Pustaka Babussalam, 1991.

Saifullah. "Pembaruan Pendidikan Islam di Aceh: Studi Historis tentang Jami'ah Almuslim 1929-2010." Disertasi: Magister Program of IAIN Sumatera Utara, 2012.

Siregar, L. Hidayat. "Tarekat Naqsyabandiyah Syaikh Abdul Wahab Rokan," dalam MIQOT: Jurnal Ilmu-ilmu Keislaman, Vol. XXXV. No. 1, 2011.

Steenbrink, Karel A. Pesantren Madrasah Sekolah: Pendidikan Islam dalam Kurun Modern. Jakarta: LP3S, 1994.

Yunus, Mahmud. Sejarah Pendidikan Islam di Indonesia. Jakarta: Mutiara Sumber Widya, 1995.

Zuhdi, Sulaiman. Langkat dalam Kilatan Selintas Jejak Sejarah dan Peradaban. Stabat: Kantor Perpustakaan, Arsip dan Dokumentasi Kabupaten Langkat, 2014. 